\title{
Diver ecotourism and disturbance to reef fish spawning aggregations: It is better to be disturbed than to be dead
}

\author{
William D. Heyman ${ }^{1, *}$, Liam M. Carr ${ }^{1}$, Phillip S. Lobel $^{2}$ \\ ${ }^{1}$ Coastal and Marine Geography Group, Department of Geography, Texas A\&M University, College Station, \\ Texas 77843-3147, USA \\ ${ }^{2}$ Biology Department, Boston University, Boston, Massachusetts 02215, USA
}

\begin{abstract}
Dive tourism, with proper diver training, is often suggested as an environmentally benign and economically viable alternative to commercial fishing of coral reef fishes, affording, for example, unique opportunities to see large schools of spawning fish or encounter whale sharks Rhincodon typus. Yet, the ancillary effects of groups of divers disrupting fish spawning aggregations (FSAs) must be assessed. We examined over $9 \mathrm{~h}$ of video footage (extracted from over $100 \mathrm{~h}$ of underwater video) filmed at FSA sites in Belize. The footage captured divers interacting with schools of snappers and groupers as they aggregated to spawn, as well as showing the arrival of whale sharks. Diver behaviors included both video recording and flash still photography of fish schools and tagging of whale sharks. We filmed 746 unique diver-school interactions that included total observations of approximately 200000 snappers, 4700 Nassau groupers Epinephelus striatus and 200 whale sharks. We recorded 180 spawning events, only 105 of which showed divers disturbing aggregating schools, which affected an estimated 2100 snappers and 90 groupers. We conclude that small groups of experienced divers, following a code of responsible diving centered upon the precautionary principle and sensitivity to fish schooling behaviors, do not negatively affect schooling or spawning behaviors. Though further research is needed to assess the effects of boat traffic and larger groups of less experienced divers, dive ecotourism at fish spawning areas represents an economically attractive and less exploitative alternative to commercial fishing.
\end{abstract}

KEY WORDS: Fish spawning aggregation · Dive ecotourism • Marine protected area (MPA)

Resale or republication not permitted without written consent of the publisher

\section{INTRODUCTION}

The protection of reef fish spawning aggregations (FSAs) and their spawning habitats are integral to the restoration of fish stocks and maintenance of marine biodiversity throughout the Caribbean Sea. Many Caribbean FSA sites harbor aggregations of several commercially important species (e.g. Claro \& Lindeman 2003, Heyman \& Kjerfve 2008, Kobara \& Heyman 2010), so reserves at these sites designed to protect one species can also provide benefits to others. FSAs are concentrated both temporally and spatially (Domeier \& Colin 1997) to produce high numbers of offspring.
Such schooling behavior is necessary to support viable cohort classes in the face of high larval and juvenile mortality rates (Polovina \& Ralston 1987). From a fishery perspective, the highly predictable times and locations of FSAs have led to unsustainable fishing pressure and subsequent stock depletion. Many FSAs in the Caribbean have been fished to the point of collapse over the past several decades (Sadovy de Mitcheson et al. 2008). Remaining FSAs, which in the past may have included tens of thousands of individual fishes, presently have populations several orders of magnitude lower than historical records (Beets \& Friedlander 1998, Sala et al. 2001, Burton et al. 2005). 
Nevertheless, there remain several healthy FSAs, many of which are located along the Meso-American Barrier Reef System in Belize (Kobara \& Heyman 2010). Reserves and marine protected areas (MPAs) centered upon spawning sites and seasons are one tool used by resource managers to reduce fishing effort and rebuild stocks, both in Belize (Heyman \& Requena 2002, Cho 2005) and across the Caribbean (Sluka et al. 1997, Beets \& Friedlander 1998, Gell \& Roberts 2003, Burton et al. 2005, Nemeth 2005). Yet these management plans rarely account for every ecological relationship or potential anthropogenic disturbance. Fish life history and behaviors, patterns of mobility, migratory pathways and connectivity between critical habitats are crucial considerations that may be overlooked or considered at inappropriate scales (Guénette et al. 1998). Many anthropogenic effects, such as continued, displaced or relocated fishing effort, deterioration of associated habitats, pollution or other physical effects may be underestimated or missed completely, thus reducing or forfeiting the benefits initially expected from the creation of the MPA. Where MPAs are unable to demonstrate the benefits proposed, public support often wanes (Agardy 2003, Cook \& Heinen 2005, Kaiser 2005). To help generate and maintain this necessary public support, MPA plans should encourage the development of economically attractive alternatives for natural resource use that are less exploitative and more conservation-minded.

Ecotourism ventures, properly supported and implemented, can often provide real economic and social benefits to both local and global economies while encouraging resource and ecological conservation (Honey 1999, Carr \& Mendelsohn 2003, Krüger 2005). However, there remain important questions as to whether ecotourism is sufficiently benign in terms of its own suite of negative effects on both the natural ecosystem and the local community and their resource needs over multiple temporal and spatial scales (Davis \& Tisdell 1996, Lindberg et al. 1996, Scheyvens 1999, Stem et al. 2003, Hawkins et al. 2005).

Our research examines this last point as it relates to dive tourism, particularly at FSAs. Dive tourism is highly valued at local, regional and larger scales (Davis \& Tisdell 1996, Arin \& Kramer 2002, Carr \& Mendelsohn 2003). It often also meets Honey's (1999) definition of ecotourism that such ventures center on education and conservation programs of unspoiled areas while providing low impact yet viable economic opportunities for local communities. Dive tourism is often centered around this very premise, offering exclusive access to sights and experiences that include shark and coral spawning encounters, remote shipwreck diving, and other unique and engaging destinations and activities. Where such dive ventures become economically successful, support for conservation and protection of these tourism resources increases (Williams \& Polunin 2000) and measurable ecological benefits can also be seen (Dixon et al. 1993, Rudd \& Tupper 2002, Sorice et al. 2007). Dive tourism reduces negative impacts of fishing by drawing fishers and boat captains into the industry while developing potentially sustainable uses of FSAs. Finally, successfully siting and promoting MPAs often leads to the establishment of dive tourism ventures and an ecotourism economy in those communities (Pendleton 1995, Green \& Donnelly 2003).

Dive tourism, however, is not necessarily environmentally benign. Education and enforcement are paramount for ensuring that the development of a tourism economy does not simply exchange one set of issues for another. Problems of access and unforeseen political and economic issues may arise, complicating or reducing expected positive outcomes. Excluding people within the fishing industry from perceived or real benefits of the tourism economy can hamper the longterm viability of conservation goals. More directly, supplanting fishing economies with dive tourism increases the risk of dive-related damage to the environment (Rouphael \& Inglis 1997, Hawkins et al. 1999, 2005, Barker \& Roberts 2004, Burke \& Maidens 2004). Environmental and economic forfeitures from a poorly managed dive industry can be large in both scope and duration (Liddle \& Kay 1987, Davis \& Tisdell 1996).

Our research specifically examines whether dive tourism negatively disrupts FSAs, disturbing spawning efforts in such a manner as to negatively affect reproduction potential and the long-term health of these fish populations, both ecologically and as a resource. If there are identifiable disturbances to FSAs and fish populations, what level of interaction by divers is required to cause such a disturbance, and most critically, how likely is it that a disturbed aggregation will forgo spawning as a response?

\section{MATERIALS AND METHODS}

Study area. This study was conducted largely at Gladden Spit, Belize, a well-documented multispecies spawning aggregation site located at a reef promontory $\left(16^{\circ} 35^{\prime} \mathrm{N}, 88^{\circ} \mathrm{W}\right)$ adjacent to the $1000 \mathrm{~m}$ isobath (Heyman \& Kjerfve 2008). One multispecies FSA is situated within the Gladden Spit and Silk Cayes Marine Reserve (GSSCMR). Because this FSA site has unique geomorphology (Heyman \& Kjerfve 2008) and oceanographic conditions (Ezer et al. 2005) it is an important aggregation site throughout the year for at least 17 species of fish (Heyman \& Requena 2002, Heyman \& Kjerfve 2008). GSSCMR has also become the center 
for a growing marine tourism industry in southern Belize. The reserve was established by the Belizean government in 2000 (Ministry of Agriculture and Fisheries 2000) and is currently managed by a partnership between a local non-government organization and Belize's Ministry of Agriculture and Fisheries. Gladden Spit provides protection to FSAs through defined conservation zones that prohibit or limit negative human impacts without overly restricting access to the reserve (via a General Use Zone) for stakeholder groups. It thereby provides important revenue streams into the local economy through both a managed commercial fishery and recreational tourism ventures. Though the majority of observations were from Gladden Spit, $22 \%$ were included from 2 additional multispecies FSA sites in Belize - Turneffe Elbow and Sandbore, Lighthouse Reef (described in Kobara \& Heyman 2010).

Data collection and analysis. Over a period of $88 \mathrm{~d}$ centered around the peak spawning season for groupers (December through February) and snappers (March through June) from 1999 through 2008, researchers used digital video cameras (Sony TRV 900 and Sony VX 1000) placed in underwater housings (Gates Underwater Products) to record over $100 \mathrm{~h}$ of courtship and spawning behaviors of snappers and groupers. Unless otherwise noted, all filming was conducted during late afternoon hours, $90 \mathrm{~min}$ before to $10 \mathrm{~min}$ after sunset, to coincide with observed increases in aggregating and spawning by schools of fishes. All relevant footage that illustrated interactions between divers and reef fish was extracted for the present analysis.
For each event we (1) identified fish to the species level; (2) described fish schooling behavior using the following categories (circling, courtship coloration, descending, milling, rising, rushing, schooling, slow swim/resting, spawning) (Table 1); (3) estimated the number of individuals in the school recorded within the video frame; (4) described the approximate position of the school in the water column using the following categories (bottom, midwater, surface); (5) reported the numbers of divers (including camera operator) and the behavior of the diver closest to the aggregation (approaching, following, stationary); (6) estimated the closest distance divers came to the school $(0.5,1,2,3,5,7$, $10,15,20 \mathrm{~m}) ;(7)$ identified any discernible change in fish behavior (color change, fin twitch, flight, hiding, maintaining distance, parting, slow flight, turning away from diver) (Table 2) and the number of disturbed fish; (8) recorded if disturbed fish returned to their original behavior, which included numbers and time (s) to revert to original behavior; (9) recorded any courtship or spawning events and (10) reported each clip duration (s), date and number of days from the nearest full moon (from $8 \mathrm{~d}$ before to $8 \mathrm{~d}$ after). Though each event may have had a range of behaviors and responses at the level of an individual fish, we reported only the most common behavior observed throughout the school and the prevalent response by the school to the divers. We made special notes on other observed behaviors within the schools to the level of small groups or individual fish, although these notes were not used for this analysis. Each event was extracted from the original footage,

Table 1. Descriptions of typical behaviors of undisturbed reef fishes at fish spawning aggregations sites (adapted from Domeier \& Colin 1997 and Heyman et al. 2005)

\begin{tabular}{ll} 
School behavior & \multicolumn{1}{c}{ Behavior description } \\
\hline Circling & $\begin{array}{l}\text { A densely formed school swimming in a unified circular direction around a central axis at a steady } \\
\text { speed. The school, as a whole, shows no vertical movement through the water column. Circling } \\
\text { schools are frequently observed near the seafloor and occur prior to rising behaviors. } \\
\text { Some fishes assume one or more species-specific courtship patterns of coloration that are different } \\
\text { from the non-courtship color phase. The percentage of fishes exhibiting courtship coloration } \\
\text { increases as spawning approaches. }\end{array}$ \\
A densely formed school swimming at a quickened speed while moving vertically down through \\
the water column. Descending schools often form immediately after upward rushes to spawn.
\end{tabular}


Table 2. Descriptions of observable disturbance behaviors of fishes (adapted from Pitcher 1986, Domeier \& Colin 1997, Godin 1997 and Smith 1997)

\begin{tabular}{ll}
\hline Disturbed behavior & \\
\hline $\begin{array}{l}\text { Color change } \\
\text { Fin twitch }\end{array}$ & $\begin{array}{l}\text { The fish reverts to non-courtship coloration. } \\
\text { The fish stops its swimming, tensing its fins. Fin twitches are immediate precursors to flight } \\
\text { behaviors. } \\
\text { Flight }\end{array}$ \\
The fish makes a sudden change in direction followed by a quick burst of speed away from the \\
diver. Flight is considered to be a major disturbance and energy-consuming. \\
The fish seeks the safety of shelter. Hiding behaviors were only seen in members of the \\
family Serranidae.
\end{tabular}

named, filed and stored using Final Cut Pro v. 6.0. For fish school size, exact counts were made when possible. Where precise numbers are given, these are a result of low counts for some interactions and of adding and averaging various numbers. Otherwise, estimates were made to the nearest 100 fish based both on video and written records of the dives. Two researchers corroborated all video-based observations independently. Analyses of diver disturbances focused on the spawning events of 3 members of the snapper-grouper complex, as well as on whale sharks Rhincodon typus. The effects of flash photography and video lights on fish behavior were recorded, although the limited number of observations prevented detailed analysis. Complementary studies on the effects of diver and boat noises and the use of rebreathers on aggregating fish behavior were conducted concurrently with this study; however, these results are not reported here.

\section{RESULTS}

From the compiled video, $561 \mathrm{~min}$ (9 h $22 \mathrm{~min}$ ) were extracted, comprising 746 unique events showing fish and diver behavior interactions (Table 3 ). No event revealed a range of behaviors and responses at the level of small groups of fish which differed from those identified for the entire school. The duration of these events ranged from 2 to $412 \mathrm{~s}$, with a mean $( \pm \mathrm{SD})$ of $45 \pm 46 \mathrm{~s}$. Of these 746 events, 213 show aggregation activity of Cubera snapper Lutjanus cyanopterus, 184 of dog snapper L. jocu and 114 of Nassau grouper Epinephelus striatus. Other members of the snapper-grouper complex-mutton snapper L. analis, red hind E. guttatus, black grouper Mycteroperca bonaci, tiger grouper $M$. tigris, yellowfin grouper $M$. venenosa and yellowtail snapper Ocyurus chrysurus - accounted for 21 events. There were an additional 175 events dominated by the presence of the 'charismatic megafauna' whale shark and 39 events that focused on various species of aggregating jacks (Carangidae). The footage contained 180 spawning events, including 100 involving L. cyanopterus, 71 involving $L$. jocu and 7 involving E. striatus. The following section details the observed disturbances for these 3 species and Rhincodon typus. All mean values are given \pm SD.

\section{Observed disturbances}

\section{Lutjanus cyanopterus}

A total of 213 events, illustrating interactions between divers and aggregated Lutjanus cyanopterus from 1999 to 2008, were captured in $199 \mathrm{~min}$ of footage. All events were captured from $2 \mathrm{~d}$ before to $9 \mathrm{~d}$ after full moon in the months of April-June, August, November and December. Only 1030 of 92870 (1.1\%) fish observed responded to the actions or presence of a diver, averaging $36 \pm 48$ fish over 29 observed disturbance events (Table 3). All disturbed fish returned to their original behavior prior to the end of each recorded interaction event. There were 100 observed spawning events captured, and in no case did divers prevent spawning rushes of $L$. cyanopterus.

Of the 7 categorized initial behaviors, the most common events recorded involved Lutjanus cyanopterus 
Table 3. Summary data for diver interactions with reef fish spawning aggregations. Mean values include $\pm \mathrm{SD}$. nd: no data

\begin{tabular}{|c|c|c|c|c|c|c|c|c|c|}
\hline $\begin{array}{r}\mathrm{T} \\
\mathrm{o} \\
\mathrm{ac} \\
\mathrm{s}\end{array}$ & $\begin{array}{l}\text { Total no. } \\
\text { of inter- } \\
\text { actions by } \\
\text { species }\end{array}$ & $\begin{array}{c}\text { Mean } \\
\text { duration of } \\
\text { interactions } \\
\text { (s) }\end{array}$ & $\begin{array}{l}\text { No. of } \\
\text { distur- } \\
\text { bances }\end{array}$ & $\begin{array}{l}\text { Mean } \\
\text { duration } \\
\text { of distur- } \\
\text { bances (s) }\end{array}$ & $\begin{array}{c}\text { Mean no. of } \\
\text { individuals } \\
\text { per event }\end{array}$ & $\begin{array}{c}\text { Mean no. of } \\
\text { disturbed } \\
\text { individuals }\end{array}$ & $\begin{array}{l}\text { No. of } \\
\text { midwater } \\
\text { events }\end{array}$ & $\begin{array}{l}\text { No. of } \\
\text { bottom } \\
\text { events }\end{array}$ & $\begin{array}{c}\text { Mean no } \\
\text { of days } \\
\text { after full } \\
\text { moon }\end{array}$ \\
\hline Lutjanus cyanopterus & 213 & $56 \pm 49$ & 29 & $3 \pm 1$ & $436 \pm 611$ & $36 \pm 48$ & 161 & 52 & $2.0 \pm 2.6$ \\
\hline Lutjanus jocu & 184 & $52 \pm 51$ & 12 & $5 \pm 7$ & $577 \pm 636$ & $97 \pm 137$ & 166 & 18 & $1.4 \pm 3.2$ \\
\hline Epinephelus striatus & 114 & $24 \pm 17$ & 45 & $5 \pm 4$ & $41 \pm 75$ & $2 \pm 2$ & 7 & 106 & $4.6 \pm 2.6$ \\
\hline Rhincodon typus & 175 & $36 \pm 40$ & 4 & $5 \pm 3$ & $1.2 \pm 0.6$ & 1 & 174 & 1 & $3.6 \pm 3.0$ \\
\hline Lutjanus analis & 3 & $19 \pm 17$ & 1 & 2 & 37 & 1 & 2 & 1 & $2.3 \pm 1.2$ \\
\hline Ocyurus chrysurus & 1 & 9 & 0 & nd & 25 & nd & 1 & 0 & 0 \\
\hline Epinephelus guttatus & 1 & 19 & 1 & 2 & 1 & 1 & 0 & 1 & 0 \\
\hline Mycteroperca bonaci & 6 & $18 \pm 12$ & 1 & 4 & $2 \pm 1$ & 1 & 0 & 6 & $4.5 \pm 1.2$ \\
\hline Mycteroperca tigris & 9 & $90 \pm 148$ & 2 & 5 & $3 \pm 3$ & $8 \pm 4$ & 0 & 9 & $5.3 \pm 1.8$ \\
\hline Mycteroperca venenosa & sa 1 & 201 & 1 & 7 & 10 & 10 & 0 & 1 & 8 \\
\hline Caranx spp. & 39 & $3 \pm 2$ & 9 & $3 \pm 1$ & $386 \pm 435$ & $97 \pm 155$ & 36 & 3 & $3.0 \pm 2.3$ \\
\hline
\end{tabular}

milling (64 of 213 events), with only 10 of these events including any observed disturbance to the fish (Table A1). The similar, but more organized, schooling behavior accounted for 20 events and 7 disturbances. Together, these 2 behavior types led to 12 spawning instances $(12 \%$ of total number of spawning events reported). Conversely, the similar behaviors of rising and rushing totaled 76 events, of which there were 70 spawning events and only 5 reported disturbances.

\section{Lutjanus jocu}

There were 184 events, captured in 160 min that involved schools of Lutjanus jocu. All events were captured from $2 \mathrm{~d}$ before to $9 \mathrm{~d}$ after full moon in November-January, April-June and August. There were 12 identified disturbances, affecting an average of $97 \pm$ 137 ind. (Table 3). An estimated 106000 L. jocu were reported (Table A2), with 1120 exhibiting disturbed responses (1.05\% of estimated population). There were 71 observed spawning events, though we captured no footage of divers preventing spawning rushes of $L$. jocu.

Like Lutjanus cyanopterus, L. jocu schools did not appear to be disturbed by the presence of divers. The vast majority of disturbed $L$. jocu (94\%) reacted to the presence of a diver by either maintaining their distance while remaining in an intact school or by parting around the diver. Only 20 fish rapidly changed their swimming direction due to the presence of divers.

\section{Epinephelus striatus}

There were 114 events, captured over 46 min from 1999 to 2003, involving Epinephelus striatus schools or individuals. All events were captured from $1 \mathrm{~d}$ before to $9 \mathrm{~d}$ after full moon in December and January. There were 45 disturbances, averaging $2 \pm 2$ fish per event, affecting an estimated 90 fish out of ca. 4700 counted ( $1.9 \%$ of estimated population). There were 7 identified instances of spawning and 32 instances of courtship behaviors (Table A3). There were no observed instances of spawning disruption by diver behavior or proximity.

Behavioral responses of Epinephelus striatus to divers were different from those of the snappers. In some instances, and when approached from above, E. striatus completed a slow evasive response, maintaining a safe distance from divers $(2.8 \pm 0.9 \mathrm{~m})$. Yet when divers approached E. striatus from the side, they were able to get much closer $(1.1 \pm 0.8 \mathrm{~m})$ than they could to snappers $(4.7 \pm 3.3 \mathrm{~m})$. We counted 34 approaches as disturbing E. striatus, yet they involved only 55 fish (Table A3).

\section{Rhincodon typus}

There were 175 events where Rhincodon typus was present, totaling 212 whale sharks over 107 min (Table 3). R. typus were present from $2 \mathrm{~d}$ before to $9 \mathrm{~d}$ after the April, May and June full moons. There were 4 identified disturbance events, each of which occurred during a concurrent tagging study; shark behavior did not appear to be in response to diver behavior, but rather a reaction to the shark being tagged dorsally.

\section{DISCUSSION AND CONCLUSION}

In dive tourism, the experience of the diver is paramount, and FSA diving offers a tantalizing new type of experience for well-traveled divers. However, tourist divers or boat traffic can affect marine animal behav- 
ior, as documented for Indo-Pacific bottlenose dolphins Tursiops aduncus (Stensland \& Berggren 2007), whale sharks (Quiros 2007) and white sharks Carcharodon carcharias (Laroche et al. 2007). This creates a paradox for managers who wish to increase diver numbers but still conserve the species (Sorice et al. 2003). Our research has shown that small groups of properly trained divers have little to no effect on snapper or grouper FSAs or whale sharks.

Fishes in spawning aggregations avoid divers in the same manner as they respond to the presence of other large animals (particularly whale sharks) passing near or through their schools. Our observations indicate that the likelihood of disturbing a school of fish is greatest when divers are positioned directly above rising schools of snappers $(<3 \mathrm{~m}$ distance). Our footage showed that such responses were also seen with similarly positioned whale sharks. School responses were primarily low-energy avoidance behaviors (i.e. parting or maintaining distance), although in a few instances, short duration, potentially high-energy responses (i.e. fin twitches and turning away behaviors that could lead to flight) were observed. These responses, if transmitted through an aggregating school, may be sufficient to prevent or delay spawning efforts, yet our video showed no evidence that such responses occurred throughout a school or that they persisted. Though numbers of aggregating Lutjanus cyanopterus and Epinephelus striatus have increased at Gladden Spit since their protection in 2003 (Heyman \& Wade 2007), illustrating that disturbance is minimal and management is working, we caution that our results are preliminary and should be interpreted with care.

With fishery management being increasingly restrictive, identifying and developing viable economic alternatives for affected fishers will be necessary to offset the economic losses that come with gear restrictions, seasonal and/or spatial closures, and license restructuring designed to reduce access to a fishery. Marine ecotourism is a viable alternative in general, and dive tourism on reef FSAs may represent a more targeted alternative to fishing highly vulnerable and ecologically important FSA sites in the Caribbean Sea. Sala et al. (2001) estimated that limited tourist diving on grouper FSAs in Belize would produce 20 times the income produced from fishing it. Hargreaves-Allen (2009) calculated that annual net benefits of US\$ 4 million were accrued from the tourism at Gladden Spit-Silk Cayes Marine Reserve, compared with only $\$ 315000$ needed to manage that reserve for the year. Given the unique nature of diving on FSAs containing thousands of large individual fishes, some of them endangered species like Epinephelus striatus, it is likely that market forces exist that could drive rates higher, thereby providing even higher benefits to the region and tourism industry. Dive tourism may provide the necessary economic engine that can fuel conservation and mitigate the negative effects for displaced fishers.

Existing regulations for Gladden Spit are rather restrictive for the relatively small area in which fishes aggregate to spawn. All dive masters and boats are permitted to operate in the area only after extensive training and appropriate certification. Numbers are restricted to 6 divers per dive master, 12 divers per boat, and 2 boats in the aggregation zone at a time (by lottery) for a total of $1.5 \mathrm{~h}$ each, and divers are limited to a maximum depth of $24 \mathrm{~m}$ as a precaution against them creating disturbances to aggregating fishes (Ministry of Agriculture and Fisheries 2000, Southern Environmental Association unpubl. regulations). A shared motivation to manage Gladden Spit with a conservation-minded and precautionary approach has resulted in a program of adaptive regulations that are adjusted each year through stakeholder meetings that include guides, fishers, and relevant authorities and scientists. Regulations could be adapted to also limit physical distance to aggregations, similar to already existing rules concerning divers and whale sharks (minimum distance of $4.5 \mathrm{~m}$ ). Most critically, for such regulations to be successful, dive operators must continue to educate and train divers on proper dive etiquette amongst these schools, insist upon buoyancy control, and emphasize the risks of unsafe diving to both divers and FSAs.

Our results can be cautiously applied in other areas, with several caveats. The majority of our footage focused on Lutjanus cyanopterus and L. jocu aggregations at Gladden Spit. The behaviors observed in this study by experienced and highly trained divers should be compared cautiously with other species of aggregating fishes or other areas where physical conditions and diver numbers and behaviors may be different. Epinephelus striatus in this study, for example, were more apt to be disturbed than were the snapper species. These disturbances arise from differences in behavior of the fishes, which in turn elicit different diver behaviors. Flash photography and video lights did not appear to affect the behavior of spawning snappers beyond those effects elicited by diver presence. Our data do not include any observations of flash photography on groupers. In summary, we encourage further research, deliberation and restraint in developing dive tourism, particularly at larger scales than we have recorded.

Though we show that divers generally do not disturb FSAs, we do not presume this to be impossible. Shortterm behavioral responses including our observations need to be evaluated carefully. Initial interpretations of short-term behavioral responses to boat traffic seemed 
insignificant for Indo-Pacific bottlenose dolphins, but Bejder et al. (2006) reinterpreted those results in light of declining sightings of this species in the study area over the long term, suggesting that those individuals that are more sensitive to disturbance may not return to the site of the interaction. We believe that the daily presence of boat traffic, fishing or diving at known FSA sites, in sufficient densities over time, may create levels of disturbances to the point that schools shift their aggregation timing and site selection. Such shifts invariably affect the ecological fitness and reproductive potential of a fish population, although these effects may be hard to quantify or even describe as a net positive or negative. Such thought and care is borne out by observations made in 2008 at Gladden Spit that a previously 'permanent' spawning aggregation of Lutjanus cyanopterus had moved more than 1 mile $(1.6 \mathrm{~km})$ to the south (W. D. Heyman unpubl. data) after $9 \mathrm{yr}$ of documented site fidelity within the MPA. While this observation and its possible causes are not discussed in this paper, we suggest that FSA site-shifting presents a challenge to policymakers and managers. For example, in small MPAs a small shift in FSA location may place the aggregation outside of the MPA boundaries, thereby nullifying their protection.

Our findings represent a preliminary study. Research should be expanded to determine the impacts of larger groups, less experienced divers, and boat traffic and sounds on FSA site fidelity, avoidance behavior and abundance over time. These studies should evaluate differences between species and sites as we have found that snappers are less affected than groupers. Developing a body of studies will build support for responsible dive tourism as a tool for conservation and management of FSA sites.

In conclusion, diving at an FSA site did not negatively affect aggregating and spawning fishes in the short term. In the Caribbean, dive tourism can provide local economic revenue streams that make up for forfeitures in the fishery sector while providing work opportunities (e.g. boat captains, dive masters, tour operators) for displaced fishers. To ensure that any expansion of dive tourism at FSA sites does not affect schooling fishes or their reproductive potential, we encourage a precautionary approach that examines, and properly responds to, the effects of diving and dive tourism at various scales and levels of interaction.

Acknowledgements. We thank L. Garbutt, L. Kaufman and B. Young for valuable discussions that helped to initiate this analysis. We thank the Department of Fisheries of Belize and J. Azueta for permission to conduct this research, and are grateful to Southern Environmental Association (SEA) and L. Garbutt for access to the Gladden Spit Reserve. We thank the myriad of tour guides, park rangers, and SEA biologists for assistance and partnership over many years. We specifically thank E. Cuevas,
S. Garbutt and J. Young for boat captaining, guiding and safety. Thanks to L. Lobel for field assistance in 2008. We are grateful for the use of underwater video footage provided by $\mathrm{C}$. and R. Foster, R. Requena, E. George and S. Hoare. We also thank 3 anonymous reviewers for helpful comments that have strengthened the manuscript. Funding for this research was provided by Conservation International's Marine Managed Area Science Program, The Nature Conservancy and Texas A\&M University's College of Geosciences.

\section{LITERATURE CITED}

Agardy T (2003) Dangerous targets? Unresolved issues and ideological clashes around marine protected areas. Aquat Conserv Mar Freshw Ecosyst 13:353-367

Arin T, Kramer RA (2002) Divers' willingness to pay to visit marine sanctuaries: an exploratory study. Ocean Coast Manag 45:171-183

Barker NHL, Roberts CM (2004) Scuba diver behaviour and the management of diving impacts on coral reefs. Biol Conserv 120:481-489

> Beets J, Friedlander A (1998) Evaluation of a conservation strategy: a spawning aggregation closure for red hind, Epinephelus guttatus, in the U.S. Virgin Islands. Environ Biol Fishes 55:91-98

Bejder L, Samuels A, Whitehead H, Gales N (2006) Interpreting short-term behavioural responses to disturbance within a longitudinal perspective. Anim Behav 72: 1149-1158

Burke L, Maidens J (2004) Reefs at risk in the Caribbean. World Resources Institute, Washington, DC

Burton ML, Brennan KJ, Muñoz RC, Richard O, Parker J (2005) Preliminary evidence of increased spawning aggregations of mutton snapper (Lutjanus analis) at Riley's Hump two years after establishment of the Tortugas South Ecological Reserve. Fish Bull 103:404-410

Carr LM, Mendelsohn R (2003) Valuing coral reefs: a travel cost analysis of the Great Barrier Reef. Ambio 32:353-357

Cho L (2005) Marine protected areas: a tool for integrated coastal management in Belize. Ocean Coast Manag 48: 932-947

Claro R, Lindeman KC (2003) Spawning aggregation sites of snapper and grouper species (Lutjanidae and Serranidae) on the insular shelf of Cuba. Proc Gulf Caribb Fish Inst 14: 91-106

Cook GS, Heinen JT (2005) On the uncertain costs and tenuous benefits of marine reserves: a case study of the Tortugas Ecological Reserve, South Florida, USA. Nat Areas J 25:390-396

Davis D, Tisdell C (1996) Economic management of recreational scuba diving and the environment. J Environ Manag 48:229-248

Dixon JA, Scura LF, van't Hof T (1993) Meeting ecological and economic goals: marine parks in the Caribbean. Ambio 22:117-125

Domeier M, Colin PL (1997) Tropical reef fish spawning aggregations: defined and reviewed. Bull Mar Sci 60: $698-726$

Ezer T, Thattai DV, Kjerfve B, Heyman WD (2005) On the variability of the flow along the Meso-American Barrier Reef System: a numerical model study of the influence of the Caribbean current and eddies. Ocean Dyn 55:458-475

- Gell F, Roberts CM (2003) Benefits beyond boundaries: the fishery effects of marine reserves. Trends Ecol Evol 18: 448-455

Godin JGJ (1997) Evading predators. In: Godin JGJ (ed) 
Behavioural ecology of teleost fishes. Oxford University Press, Oxford

Green E, Donnelly R (2003) Recreational scuba diving in Caribbean marine protected areas: Do the users pay? Ambio 32:140-144

Guénette S, Lauck T, Clark C (1998) Marine reserves: from Beverton and Holt to the present. Rev Fish Biol Fish 8: 251-272

Hargreaves-Allen V (2009) Is marine conservation a good deal? The value of a protected reef in Belize. Conservation Policy in Brief 7. Conservation Strategy Fund, Sebastopol, CA. www.conservation-strategy.org

Hawkins JP, Roberts CM, Van't Hof T, de Meyer K, Tratalos J, Aldam C (1999) Effects of recreational scuba diving on Caribbean coral and fish communities. Conserv Biol 13: 888-897

Hawkins JP, Roberts CM, Kooistra D, Buchan K, White S (2005) Sustainability of scuba diving tourism on coral reefs of Saba. Coast Manag 33:373-387

Heyman WD, Kjerfve B (2008) Characterization of transient multi-species reef fish spawning aggregations at Gladden Spit, Belize. Bull Mar Sci 83:531-551

Heyman WD, Requena N (2002) Status of multi-species spawning aggregations in Belize. The Nature Conservancy, Punta Gorda

Heyman WD, Wade B (2007) Status of reef fish spawning aggregations in Belize. Proc Gulf Caribb Fish Inst 58: 301-306

> Heyman WD, Kjerfve B, Graham RT, Rhodes KL, Garbutt L (2005) Spawning aggregations of Lutjanus cyanopterus (Cuvier) on the Belize Barrier Reef over a 6 year period. J Fish Biol 67:83-101

Honey M (1999) Ecotourism and sustainable development: Who owns paradise? Island Press, Washington, DC

Kaiser MJ (2005) Are marine protected areas a red herring or fisheries panacea? Can J Fish Aquat Sci 62:1194-1199

Kobara S, Heyman WD (2010) Sea bottom geomorphology of multi-species spawning aggregation sites in Belize. Mar Ecol Prog Ser 405:243-254

Krüger O (2005) The role of ecotourism in conservation: panacea or Pandora's box? Biodivers Conserv 14:579-600

Laroche RK, Kock AK, Dill LM, Oosthuizen WH (2007) Effects of provisioning ecotourism activity on the behavior of white sharks Carcharadon carcharias. Mar Ecol Prog Ser 338:199-209

Liddle MJ, Kay AM (1987) Resistance, survival and recovery of trampled corals on the Great Barrier Reef. Biol Conserv 42:1-18

Lindberg K, Enriquez J, Sproule K (1996) Ecotourism questioned: case studies from Belize. Ann Tourism Res 23: 543-562

Ministry of Agriculture and Fisheries (2000) Gazette no. 68/2000. Government of Belize, Belmopan, p 226
Nemeth RS (2005) Population characteristics of a recovering US Virgin Islands red hind spawning aggregation following protection. Mar Ecol Prog Ser 286:81-97

Pendleton LH (1995) Valuing coral reef protection. Ocean Coast Manag 26:119-131

Pitcher TJ (1986) Functions of shoaling behavior in teleosts. In: Pitcher TJ (ed) The behaviour of teleost fishes. Chapman \& Hall, London

Polovina JJ, Ralston S (1987) Tropical snappers and groupers: biology and fisheries management. Westview Press, London

> Quiros AL (2007) Tourist compliance to a code of conduct and the resulting effects on whale shark (Rhincodon typus) behavior in Donsol, Phillipines. Fish Res 84:102-108

Rouphael AB, Inglis GJ (1997) Impacts of recreational scuba diving at sites with different reef topographies. Biol Conserv 82:329-336

Rudd MA, Tupper MH (2002) The impact of Nassau grouper size and abundance on scuba diver site selection and MPA economics. Coast Manag 30:133-151

Sadovy de Mitcheson Y, Cornish A, Domeir M, Colin PL, Russell M, Lindeman KC (2008) A global baseline for spawning aggregations of reef fishes. Conserv Biol 22: 1233-1244

> Sala E, Ballesteros E, Starr RM (2001) Rapid decline of Nassau grouper spawning aggregations in Belize: fishery management and conservation needs. Fisheries 26(10):23-30

Scheyvens R (1999) Ecotourism and the empowerment of local communities. Tour Manag 20:245-249

Sluka R, Chiappone M, Sullivan KM, Wright R (1997) The benefits of a marine fishery reserve for Nassau grouper Epinephelus striatus in the central Bahamas. Proc 8th Int Coral Reef Symp, Panama 2:1961-1964

Smith RJF (1997) Avoiding and deterring predators. In: Godin JGJ (ed) Behavioural ecology of teleost fishes. Oxford University Press, Oxford

Sorice MG, Shafer CS, Scott D (2003) Managing endangered species with the use/preservation paradox: understanding and defining harassment of the West Indian manatee (Trichecus manutus). Coast Manag 31:319-338

Sorice MG, Oh CO, Ditton RB (2007) Managing scuba divers to meet ecological goals for coral reef conservation. Ambio 36:316-322

Stem CJ, Lassoie JP, Lee DR, Deshler DJ (2003) How 'eco' is ecotourism? A comparative case study of ecotourism in Costa Rica. J Sustainable Tourism 11:322-347

Stensland E, Berggren P (2007) Behavioural changes in female Indo-Pacific bottlnose dolphins in response to boatbased tourism. Mar Ecol Prog Ser 332:225-234

Williams ID, Polunin NVC (2000) Differences between protected and unprotected reefs of the Western Caribbean in attributes preferred by dive tourists. Environ Conserv 27: 382-391 
Appendix 1. Disturbance to reef fish by diver ecotourism

Table A1. Lutjanus cyanopterus. Summary of disturbance events showing the duration (s), distance (minimum distance between the disturbed fish and the closest diver, in $\mathrm{m}$ ), and number of disturbed individuals, grouped according to the original behavior of the fish prior to the diver-fish school interaction event. The 4 rows at the top of the table show the total no. of interaction events, the total length (time, s) of these events, and the total and mean no. of fish observed. The rows beneath the line show the reactions of the fish to these interactions (no. dist. events: no. of disturbance events) and the no. of courtship and spawning events observed. See Tables 1 \& 2 for description of behaviors

\begin{tabular}{|c|c|c|c|c|c|c|c|c|}
\hline & Circling & Descending & Milling & Rising & Rushing & Schooling & Slow swim & Total \\
\hline Total no. of interactions & 17 & 31 & 64 & 40 & 36 & 20 & 5 & 213 \\
\hline Total time & 768 & 1809 & 2916 & 3254 & 1761 & 1303 & 155 & 11966 \\
\hline No. of fish & 8680 & 17040 & 16993 & 23700 & 8025 & 18235 & 197 & 92870 \\
\hline Mean no. of fish & 511 & 550 & 266 & 593 & 223 & 912 & 39 & 442 \\
\hline Fin twitch (no. dist. events) & 0 & 0 & 2 & 1 & 0 & 0 & 0 & 3 \\
\hline No. of fish & - & - & 52 & 5 & - & - & - & 57 \\
\hline Average distance & - & - & 2.5 & 3 & - & - & - & 2.8 \\
\hline Average duration & - & - & 2 & 2 & - & - & - & 2 \\
\hline Hide (no. dist. events) & 0 & 0 & 0 & 0 & 0 & 0 & 0 & 0 \\
\hline No. of fish & - & - & - & - & - & - & - & - \\
\hline Average distance & - & - & - & - & - & - & - & - \\
\hline Average duration & - & - & - & - & - & - & - & - \\
\hline Maintain distance (no. dist. events) & 0 & 0 & 0 & 1 & 0 & 2 & 0 & 3 \\
\hline No. of fish & - & - & - & 100 & - & 300 & - & 400 \\
\hline Average distance & - & - & - & 3 & - & 2 & - & 2.5 \\
\hline Average duration & - & - & - & 3 & - & 3 & - & 3 \\
\hline Parting (no. dist. events) & 1 & 1 & 0 & 0 & 0 & 2 & 0 & 4 \\
\hline No. of fish & 100 & 100 & - & - & - & 170 & - & 370 \\
\hline Average distance & 1 & 2 & - & - & - & 1 & - & 1.3 \\
\hline Average duration & 2 & 2 & - & - & - & 3 & - & 2.3 \\
\hline Slow flight (no. dist. events) & 0 & 0 & 0 & 0 & 0 & 0 & 0 & 0 \\
\hline No. of fish & - & - & - & - & - & - & - & - \\
\hline Average distance & - & - & - & - & - & - & - & - \\
\hline Average duration & - & - & - & - & - & - & - & - \\
\hline Turn away (no. dist. events) & 0 & 3 & 8 & 1 & 2 & 3 & 1 & 18 \\
\hline No. of fish & - & 31 & 97 & 20 & 3 & 13 & 20 & 184 \\
\hline Average distance & - & 1 & 1 & 0.5 & 1 & 2 & 1 & 1.1 \\
\hline Average duration & - & 3 & 3 & 2 & 3 & 2 & 3 & 2.7 \\
\hline Spawning & 3 & 15 & 8 & 35 & 35 & 4 & 0 & 100 \\
\hline Courtship & 9 & 2 & 8 & 10 & 8 & 3 & 0 & 40 \\
\hline
\end{tabular}

Table A2. Lutjanus jocu. Summary of disturbance events as for Table A1

\begin{tabular}{|c|c|c|c|c|c|c|c|c|}
\hline & Circling & Descending & Milling & Rising & Rushing & Schooling & Slow swim & Total \\
\hline Total no. of interactions & 12 & 30 & 21 & 26 & 23 & 72 & 0 & 184 \\
\hline Total time (s) & 547 & 1879 & 795 & 1752 & 790 & 3862 & - & 9625 \\
\hline No. of fish & 5330 & 15475 & 14380 & 14955 & 5620 & 50250 & - & 106010 \\
\hline Mean no. fish & 444 & 516 & 685 & 575 & 244 & 698 & - & 527 \\
\hline Fin twitch (no. dist. events) & 0 & 0 & 0 & 0 & 0 & 0 & 0 & 0 \\
\hline No. of fish & - & - & - & - & - & - & - & - \\
\hline Average distance & - & - & - & - & - & - & - & - \\
\hline Average duration & - & - & - & - & - & - & - & - \\
\hline Hide (no. dist. events) & 0 & 0 & 0 & 0 & 0 & 0 & 0 & 0 \\
\hline No. of fish & - & - & - & - & - & - & - & - \\
\hline Average distance & - & - & - & - & - & - & - & - \\
\hline Average duration & - & - & - & - & - & - & - & - \\
\hline Maintain distance (no. dist. events) & 0 & 0 & 0 & 2 & 0 & 0 & 0 & 2 \\
\hline No. of fish & - & - & - & 130 & - & - & - & 130 \\
\hline Average distance & - & - & - & 3 & - & - & - & 3.0 \\
\hline Average duration & - & - & - & 7.5 & - & - & - & 7.5 \\
\hline
\end{tabular}


Table A2 (continued)

\begin{tabular}{|c|c|c|c|c|c|c|c|c|}
\hline & Circling & Descending & Milling & Rising & Rushing & Schooling & Slow swim & Total \\
\hline Parting (no. dist. events) & 0 & 0 & 0 & 2 & 0 & 4 & 0 & 6 \\
\hline No. of fish & - & - & - & 700 & - & 220 & - & 920 \\
\hline Average distance & - & - & - & 2 & - & 4 & - & 3.0 \\
\hline Average duration & - & - & - & 2 & - & 2 & - & 2.0 \\
\hline Slow flight (no. dist. events) & 0 & 0 & 1 & 0 & 0 & 1 & 0 & 2 \\
\hline No. of fish & - & - & 20 & - & - & 30 & - & 50 \\
\hline Average distance & - & - & 2 & - & - & 2 & - & 2.0 \\
\hline Average duration & - & - & 3 & - & - & 5 & - & 4.0 \\
\hline Turn away (no. dist. events) & 0 & 0 & 0 & 1 & 0 & 1 & 0 & 2 \\
\hline No. of fish & - & - & - & 10 & - & 10 & - & 20 \\
\hline Average distance & - & - & - & 3 & - & 1 & - & 2.0 \\
\hline Average duration & - & - & - & 2 & - & 3 & - & 2.5 \\
\hline Spawning & 2 & 8 & 4 & 16 & 23 & 20 & - & 73 \\
\hline Courtship & 1 & 1 & 4 & 5 & 5 & 18 & - & 34 \\
\hline
\end{tabular}

Table A3. Epinephelus striatus. Summary of disturbance events as for Table A1

\begin{tabular}{|c|c|c|c|c|c|c|c|c|}
\hline & Circling & Descending & Milling & Rising & Rushing & Schooling & Slow swim & Total \\
\hline Total no. of interactions & 0 & 0 & 82 & 0 & 5 & 3 & 24 & 114 \\
\hline Total time & & & 2029 & & 93 & 61 & 600 & 2783 \\
\hline No. of fish & & & 4250 & & 85 & 185 & 158 & 4678 \\
\hline Mean no. of fish & & & 52 & & 17 & 62 & 7 & 35 \\
\hline Fin twitch (no. dist. events) & 0 & 0 & 3 & 0 & 0 & 0 & 3 & 6 \\
\hline No. of fish & - & - & 14 & - & - & - & 4 & 18 \\
\hline Average distance & - & - & 3 & - & - & - & 1.7 & 2.35 \\
\hline Average duration & - & - & 3 & - & - & - & 2 & 2 \\
\hline Hide (no. dist. events) & 0 & 0 & 9 & 0 & 0 & 0 & 0 & 9 \\
\hline No. of fish & - & - & 9 & - & - & - & - & 9 \\
\hline Average distance & - & - & 3 & - & - & - & - & 3.0 \\
\hline Average duration & - & - & 2 & - & - & - & - & 2.0 \\
\hline Maintain distance (no. dist. events) & 0 & 0 & 0 & 0 & 0 & 0 & 0 & 0 \\
\hline No. of fish & - & - & - & - & - & - & - & - \\
\hline Average distance & - & - & - & - & - & - & - & - \\
\hline Average duration & - & - & - & - & - & - & - & - \\
\hline Parting (no. dist. events) & 0 & 0 & 0 & 0 & 0 & 0 & 0 & 0 \\
\hline No. of fish & - & - & - & - & - & - & - & - \\
\hline Average distance & - & - & - & - & - & - & - & - \\
\hline Average duration & - & - & - & - & - & - & - & - \\
\hline Slow flight (no. dist. events) & 0 & 0 & 25 & 0 & 0 & 0 & 0 & 25 \\
\hline No. of fish & - & - & 55 & - & - & - & - & 55 \\
\hline Average distance & - & - & 2 & - & - & - & - & 2.0 \\
\hline Average duration & - & - & 6 & - & - & - & - & 6.0 \\
\hline Turn away (no. dist. events) & 0 & 0 & 4 & 0 & 0 & 0 & 1 & 5 \\
\hline No. of fish & - & - & 7 & - & - & - & 1 & 8 \\
\hline Average distance & - & - & 3 & - & - & - & 2 & 2.5 \\
\hline Average duration & - & - & 4 & - & - & - & 2 & 3.0 \\
\hline Spawning & 0 & 0 & 2 & 0 & 5 & 0 & 0 & 7 \\
\hline Courtship & 0 & 0 & 26 & 0 & 1 & 2 & 3 & 32 \\
\hline
\end{tabular}

Editorial responsibility: Steven Morgan, Bodega Bay, California, USA
Submitted: February 4, 2010; Accepted: July 20, 2010

Proofs received from author(s): November 12, 2010 